\title{
PENINGKATAN KETERAMPILAN BERBICARA PADA PELAJARAN BAHASA INDONESIA DENGAN PENDEKATAN KOOPERATIF STRUKTURAL PADA SISWA KELAS V SD NEGERI 060890 KECAMATAN MEDAN POLONIA
}

\author{
Zulfaridah \\ Surel: zulfaridah@gmail.com
}

\begin{abstract}
ABSTRAK
Penelitian ini bertujuan untuk mendeskripsikan peningkatan Ketrampilan Berbicara bahasa indonesia dengan menggunakan pendekatan kooperatif Struktural pada siswa kelas V SD N 060898 Kecamatan Medan Maimun. Teknik yang dipakai untuk mengumpulkan data dalam penelitian ini adalah catatan lapangan (lembar observasi), dan tes, serta penugasan. Subjek penelitian adalah siswa kelas V SD N 060890 Kecamatan Medan Polonia berjumlah 36 siswa. Adapun indikator keberhasilan tindakan ditandai dengan $\geq 75 \%$ dari jumlah siswa yang mengikuti proses pembelajaran telah memperoleh nilai $\geq 70$. Hasil penelitian menunjukkan adanya peningkatan hasil belajar PKn siswa kelas V SD N 060890 Kecamatan Medan Polonia setelah menggunakan pendekatan kooperatif Struktural baik pada siklus I maupun siklus II. Pada siklus I siswa yang memperoleh nilai $\geq 70$ mengalami peningkatan sebesar 25\% dengan kondisi awal 44\% meningkat menjadi 69\% dan pada siklus II mengalami peningkatan sebesar $28 \%$ menjadi $97 \%$. Nilai rata-rata hasil belajar pada siklus I mengalami peningkatan sebesar $8,75 \%$ dengan kondisi awal 66,53 meningkat menjadi 75,27 dan pada siklus II mengalami peningkatan sebesar $10,97 \%$ menjadi 86,25 .
\end{abstract}

Kata Kunci: Bahasa Indonesia, Ketrampilan Berbicara, Pendekatan kooperatif Struktural

\section{PENDAHULUAN}

Pada hakekatnya anak-anak belajar komunikasi dengan orang lain dengan berbagai cara, namun ada halhal umum terjadi pada hampir setiap anak. Oleh karena itu dalam pembelajaran keterampilan berbahasa seorang guru harus mampu menggunakan model, metode, dan teknik serta strategi tertentu yang sesuai agar pembelajaran lebih efektif. Banyak siswa masih belum mampu bercerita dengan baik dan benar khususnya siswa kelas V SDN 060890. Hal ini dikarenakan banyak faktor yang mempengaruhi keberhasilan hasil belajar keterampilan bercerita, antara lain faktor dari guru dan faktor dari siswa itu sendiri. Faktor dari guru dalam proses kegiatan belajar mengajar (PBM) hanya memberikan pembelajaran keterampilan bercerita secara teoritis, kurang praktik dan 
kurangnya alat peraga. Faktor dari siswa kurangnya perbendaharaan kosa kata yang akhirnya dalam merangkai bahasa secara lisan masih bercampur dengan bahasa daerah.

Pengalaman empiris di akhir semester I tahun pelajaran 2009/2010 peserta didik kelas $\mathrm{V}$ di SD negeri 060890 menunjukkan adanya penguasaan Kompetensi Dasar Menanggapi cerita tentang peristiwa yang terjadi di sekitar yang disampaikan secara lisan hasilnya kurang memuaskan, artinya penguasaan pada kompetensi tersebut yang menjadi dasar dan prasarat penguasaan kompetensi dasar tidak tuntas dikuasai oleh peserta didik. Data menunjukkan dari sejumlah 43 siswa kelas $\mathrm{V}$, siswa yang memperoleh nilai di bawah Kriteria Ketuntasan Minimum (KKM) 65, hanya 34 siswa (79\%), sedangkan yang memperoleh nilai di atas KKM yaitu sebanyak 9 siswa (21\%).

Maka dari itu, guru akan mengupayakan perbaikan pembelajaran khususnya dalam penggunaan model pembelajaran agar penguasaan keterampilan menanggapi cerita tentang peristiwa yang terjadi di sekitar yang disampaikan secara lisan di kelas V semester II tahun pelajaran 2009/2010 yang akan datang menjadi lebih baik. Untuk meningkatkan keterampilan berbicara dipilih pembelajaran dengan pendekatan kooperatif yang dapat menumbuhkan rasa saling asah, asih, dan asuh (saling mencerdaskan). Siswa tidak hanya belajar dari guru, tetapi juga dari sesama siswa. (Sarwiji Suwandi) menyimpulkan bahwa sebagian besar pembelajaran bahasa Indonesia belum mampu mewujudkan siswa mahir berbahasa Indonesia. Untuk meningkatkan keterampilan berbicara dipilih pembelajaran dengan pendekatan kooperatif Struktural yang dapat menumbuhkan rasa saling asah, asih, dan asuh (saling mencerdaskan).

Berdasarkan latar belakang masalah di atas, penelitian ini dirumuskan sebagai beriku: Apakah penerapan pendekatan kooperatif dengan metode structural dapat meningkatkan keterampilan berbicara pada siswa kelas V SD $060890 \mathrm{Kec}$. Medan Polonia?

Penelitian ini bertujuan untuk meningkatkan keterampilan berbicara dalam pembelajaran Bahasa Indonesia dengan menggunakan pendekatan kooperatif metode struktural pada siswa kelas V SD 060890 Kec Medan Polonia.

Hasil penelitian ini dihaharapkan bermanfaat bagi:

1. Siswa:

a. Siswa lebih lancar dalam berbahasa Indonesia secara lisan.

b. Meningkatkan kemampuan berpikir siswa dalam menanggapi peristiwa yang terjadi di sekitarnya. 
c. Meningkatkan kreatifitas siswa

d. Menambah perbendaharaan kosa kata

2. Guru:

a. Dapat membantu guru memperbaiki proses pembelajaran keterampilan berbicara (berbahasa Indonesia).

b. Dapat menambah wawasan guru mengenai pembelajaran berbicara dengan teknik bermain peran.

\section{METODE PENELITIAN}

Penelitian tindakan kelas ini dilakukan di Sekolah Dasar Negeri 060890 Kecamatan Medan Polonia. Penelitian dilakukan pada bulan Januari sampai dengan bulan Juni 2015. Subjek dalam Penelitian yaitu siswa kelas V SD Negeri 060890 kecamatan Medan Polonia. Teknik yang dipakai untuk mengumpulkan data dalam penelitian ini adalah catatan lapangan (lembar observasi), dan tes, serta penugasan.

Analisis data yang digunakan dalam penelitian ini adalah teknik analisis diskriptif kuantitatif untuk mengetahui adanya perbedaan tingkat pemahaman siswa terhadap materi berbicara antara sebelum dan sesudah tindakan. Selain itu digunakan juga teknik analisis deskriptif.

Adapun tindakan yang disepakati adalah sebagai berikut: 1) Membuka pertemuan, 2) Mengabsen kehadiran siswa, 3) Guru menjelaskan teknik pembelajaran, 4) Guru memutar CD berisi cerita "Sangkuriang", 5) Guru membagikan kartu yang isinya tokoh- tokoh dalam cerita, 6) Setiap siswa mendapatkan satu kartu. Setiap siswa mencari pasangan yang mempunyai kartu cocok dengan kartunya.

$$
\text { Selanjutnya dilakukan }
$$

observasi dan monitoring, serta evaluasi terhadap pelaksanaan tindakan yang telah dilakukan. Kriteria keberhasilan tindakan adalah bahwa para siswa memiliki keterampilan berbicara dengan bermain peran. Evaluasi dilakukan dengan wawancara agar siswa dapat berbicara dengan bahasa yang baik dan benar. Tes digunakan untuk mengungkap tingkat pemahaman siswa mengenai konsep berbicara. Cara berbicara yang baik atau tepat antara sebelum dan sesudah tindakan ada pada siklus satu dan dua.

Selanjutnya tahap analisis dan refleksi ini dilakukan analisis, sintesis dan memaknai hasil tindakan pertama untuk kemudian disimpulkan apakah perlu merevisi gagasan umum atau mungkin memikirkan dan merencanakan kembali jenis tindakan berikutnya yang perlu diterapkan agar siswa dapat memiliki keterampilan berbicara dengan baik. Begitu seterusnya sampai tindakan ini dapat tercapai. Dalam implementasi tindakan ini guru menggunakan metode Struktural dan teknik 
pembelajaran mencari pasangan, tanya jawab, ceramah, observasi, tugas, kerja kelompok, diskusi, presentasi.

Dalam tahap persiapan pada siklus II, kegiatan yang dilakukan adalah: 1) Mengidentifikasi masalah pada siklus I, 2) Merancang pelaksanaan tindakan untuk memecahkan permasalahan yang berkaitan dengan materi pembelajaran "menanggapi cerita tentang peristiwa yang terjadi di sekitar yang disampaiakan secara lisan", 3) Menyusun format observasi dan instrumen penelitian untuk mengetahui respon siswa terhadap pembelajaran Bahasa Indonesia, keterampilan berbicara, 4) Menetapkan jenis data yang akan dikumpulkan dan teknis analisis data yang digunakan dalam PTK ini.

Pada tahap implementasi kegitan dimulai dengan:

1. Membuka pertemuan

2. Mengabsen kehadiran siswa

3. Guru menjelaskan teknik pembelajaran.

4. Guru memutar CD berisi cerita "Timun Emas"

5. Guru membagikan kartu yang isinya tokoh- tokoh dalam sebuah cerita.

6. Setiap siswa mendapatkan satu kartu.

7. Setiap siswa mencari pasangan yang mempunyai kartu cocok dengan kartunya.

8. Setiap kelompok berdiskusi tentang cerita yang telah ditampilkan melalui $\mathrm{CD}$ agar dibuat sekenario drama untuk meningkatkan perbendaharaan kata Dalam satu kelompok saling membantu.

Dilakukan observasi dan monitoring, serta evaluaisi tehadap pelaksanaan tindakan yang telah dilakukan. Kriteria keberhasilan tindakan adalah bahwa para siswa memiliki keterampilan berbicara dengan bermain peran. Evaluasi dilakukan dengan wawancara agar siswa dapat berbicara dengan bahasa yang baik dan benar.

Tes digunakan untuk mengungkap tingkat pemahaman siswa mengenai konsep berbicara. Cara berbicara yang baik atau tepat antara sebelum dan sesudah tindakan ada pada siklus satu dan dua.

Pada tahap ini dilakukan analisis, sintesis dan memaknai hasil tindakan pertama untuk kemudian disimpulkan apakah perlu merevisi gagasan umum atau mungkin memikirkan dan merencanakan kembali jenis tindakan berikutnya yang perlu diterapkan agar siswa dapat memiliki keterampilan berbicara dengan baik. Begitu seterusnya sampai tindakan ini dapat tercapai. Dalam implementasi tindakan ini guru menggunakan metode Struktural dan teknik pembelajaran mencari pasangan, tanya jawab, ceramah, observasi, 
tugas, kerja kelompok, diskusi, presentasi.

\section{HASIL DAN PEMBAHASAN}

Keterampilan berbicara secara lisan dalam pembelajaran Bahasa Indonesia masih kurang baik dan benar khususnya siswa SD Negeri 060890 kecamatan Medan Polonia. Hal ini dikarenakan banyak faktor yang mempengaruhi keberhasilan pembelajaran keterampilan bercerita, antara lain faktor dari guru dan faktor dari siswa itu sendiri. Faktor dari guru dalam proses kegiatan belajar mengajar (PBM) hanya memberikan pembelajaran keterampilan bercerita secara teoritis, kurang praktik dan kurangnya alat peraga. Faktor dari siswa kurangnya perbendaharaan kosa kata yang akhirnya dalam merangkai bahasa secara lisan masih bercampur dengan bahasa daerah. Data menunjukkan dari sejumlah 43 siswa kelas $\mathrm{V}$, siswa yang memperoleh nilai di bawah Kriteria Ketuntasan Minimum (KKM) 65, hanya 34 siswa (79\%), sedangkan yang memperoleh nilai di atas KKM yaitu sebanyak 9 siswa (21\%).

Melihat hasil belajar yang demikian guru akan mengupayakan perbaikan pembelajaran khususnya dalam penggunaan model pembelajaran agar penguasaan keterampilan menanggapi cerita tentang peristiwa yang terjadi di sekitar yang disampaikan secara lisan di kelas V semester II tahun pelajaran 2009/2010 yang akan datang menjadi lebih baik. Maka untuk meningkatkan keterampilan berbicara dipilih pembelajaran dengan model kooperatif yang dapat menumbuhkan rasa saling asah, asih, dan asuh (saling mencerdaskan). Siswa tidak hanya belajar dari guru, tetapi juga dari sesama siswa. Sarwiji Suwandi menyimpulkan bahwa sebagian besar pembelajaran bahasa Indonesia belum mampu mewujudkan siswa mahir berbahasa Indonesia.

Tahap perencanaan pada siklus I, yaitu:

1. Dilaksanakan selama 105 menit.

2. Menyusun Rencana Pelaksanaan Pembelajaran (RPP)

3. Rancangan RPP tentang materi pokok berbicara

4. Mempersiapkan fasilitas dan sarana pendukung:

a. Ruang belajar yang digunakan adalah ruang kelas $\mathrm{V}$ SD Negeri 060890 kecamatan Medan Polonia

b. Buku Pelajaran

c. Alat Peraga

5. Menyiapkan lembar penilaian

Tahap pelaksanaan dilakukan dimulai dari:

1. Pra Pembelajaran

a. Siswa dan guru berdo'a bersama.

b. Guru mengabsen siswa

c. Guru dan siswa 
mempersiapkan media dan

alat peraga yang diperlukan

2. Kegiatan Awal

Apersepsi: (Menanyakan pada peserta didik) "Mengapa kita harus mempunyai perbendahara an kosakata (Bahasa Indonesia) yang banyak? Pengetahuan prasarat "Apa yang dimaksud bercerita?

3. Kegiatan Inti

a. Guru menjelaskan teknik pembelajaran.

b. Anak di ajak memperhatikan sebuah cerita rakyat lewat layar televisi / DVD.

c. Siswa mencatat pokokpokok cerita yang didengar.

d. Guru membagi kartu ke semua siswa masing - masing satu kartu yang berisi nama tokoh dalam cerita.

Penjelasan guru langkahlangkah bermain peran.

e. Siswa berdiskusi dengan kelompoknya membuat scenario cerita.

f. Setiap kelompok memainkan drama sesuai scenario yang dibuat.

g. Guru menilai peran siswa dalam memainkan drama.

4. Kegiatan Akhir

a. Siswa dengan bimbingan guru menyimpulkan hasil pembelajaran.

b. Guru memberi penegasan materi yang telah dipelajari bersama.

c. Berkolaborasi dengan supervisor sebagai pengamat/ observer.

Tugas observer adalah mengamati jalannya pembelajaran pada siklus I dengan panduan lembar observasi yang telah tersedia. Pengumpulan data dilakukan bersama oleh guru sebagai peneliti dan supervisor yang diperoleh melalui observasi selama proses.

Dari data hasil angket diketahui bahwa sebagian besar siswa menyukai mata pelajaran pembelajaran pada siklus I. Pembelajaran pada siklus I setelah diadakan penilaian pengamatan dan penilaian perbuatan sudah menunjukkan kemajuan bila dibandingkan nilai yang dicapai oleh siswa kelas V SD Negeri 060890 kecamatan Medan Polonia.

Secara kualitatif semua kelompok diskusi melaksanakan tugas diskusi dengan baik. Hal ini diketahui dari rata-rata nilai semua indikator yang mencapai 78,43 serta dari 43 anak 36 anak (84\%) menyukai pembelajaran bahasa Indonesia dengan menggunakan pendekatan kooperatif. Dalam kegiatan pembelajaran dengan menggunakan pendekatan kooperatif metode structural dengan menggunakan teknik mencari pasangan keterampilan berbicara siswa meningkat. Hal tersebut dapat terlihat 
dalam kegiatan pembelajaran dapat membuat siswa lebih senang dan aktif dalam belajar sehingga siswa mampu memahami konsep menanggapi cerita tentang peristiwa yang terjadi di sekitar yang disampaikan secara lisan.

Dari penelitian pada siklus 1 (pertama), hasil yang didapat kurang memuaskan. Dari hasil pembelajaran dapat dilihat bahwa masih ada siswa yang belum menguasai materi. Walaupun nilai rata-rata kelas sudah 78,43 ini dirasa masih belum maksimal, karena masih ada siswa yang nilainya di bawah KKM.

Refleksi dilakukan oleh peneliti dan supervisor dengan memperhatikan saran guru teman sejawat serta kepala sekolah. Adapun hasill refleksi yang dilakukan oleh peneliti dan supervisor yaitu melalui penilaian proses dan hasil belajar dapat diketahui bahwa siswa lebih meningkat pemahamannya tentang materi berbicara.

Berdasarkan kriteria Indikator Keberhasilan Proses yaitu $75 \%$ siswa mampu memahami materi berbicara dan sebanyak $75 \%$ siswa aktif dalam pembelajaran dan kerja kelompok. Indikator keberhasilan hasil penelitian ini yaitu jika 93\% hasil evaluasi siswa mencapai Kriteria Ketuntasan Minimum (KKM 65). Aktifitas belajar siswa dan aktifitas diskusi kelompok dapat diketahui bahwa sebagian besar siswa aktif dalam mengikuti proses pembelajaran dan melaksanakan semua tugas dengan baik. Hal ini menunjukkan siswa antusias dan menyukai pembelajaran dengan menggunakan Pendekatan Kooperatif metede Struktural dengan teknik Mencari Pasangan.

Dari semua keberhasilan tersebut, ada pula beberapa kekurangan yang muncul selama pelaksanaan siklus I. Kekurangan atau kelemahan tersebut antara lain:

1. Masih ada beberapa siswa yang hasil nilainya masih di bawah KKM.

2. Waktu yang tersedia terbatas sehingga ada aktifitas belajar yang pelaksanaannya kurang maksimal.

3. Penggunaan media dan alat peraga kurang optimal

4. Kehadiran supervisor sedikit mempengaruhi aktifitas belajar siswa, karena perhatian siswa terbagi oleh keberadaan supervisor.

5. Masih ada beberapa siswa yang kurang aktif dan kreatif dalam mengikuti aktifitas belajar.

Rekomendasi untuk pembelajaran pada siklus II :

1. Perlu disusun RPP perbaikan untuk siklus II dengan memperhatikan semua kekurangan yang muncul pada siklus I.

2. Peneliti harus memperbaiki alokasi waktu untuk setiap poin kegiatan belajar.

3. Siswa perlu lebih dipersiapkan 
dengan menjelaskan tentang kehadiran supervisor dan adanya pemotretan.

\section{Pembahasan}

Hasil dari siklus II jumlah anak mencapai ketuntasan 42 anak (98\%), sedangkan yang tidak tuntas 1 anak (2\%), nilai rata-rata kelas 84,9 . Dari data yang diperoleh bahwa siswa cukup berhasil dalam menguasai materi karena persentase untuk perolehan rentang nilai $80-100$ mencapai $70 \%$ (kategori sangat baik/A). Pada siklus II masih ada 1 siswa yang masih kesulitan dalam penggunaan bahasa Indonesia secara benar dan santun (secara lisan). Siswa yang masih kesulitan dalam penggunaan bahasa Indonesia secara lisan, dikarenakan hal-hal sebagai berikut:
1. Siswa kurang aktif dalam berdiskusi

2. Siswa dalam berkomunikasi kurang percaya diri d. Upaya Perbaikan

Upaya-upaya guru di dalam mengatasi masalah - masalah tersebut di atas, agar siswa kelas V SD Negeri 060890 kecamatan Medan Polonia mampu berkomunikasi memakai Bahasa Indonesia secara lisan dengan benar dan santun, guru mewajibkan siswa menggunakan bahasa Indonesia dalam berkomunikasi di sekolah baik di dalam kelas maupun di luar kelas (kecuali dalam mata pelajaran bahasa daerah). Siswa harus banyak bertanya seandainya mengalami kesulitan dalam penggunaan Bahasa Indonesia (baik kepada guru maupun kepada teman) agar mempunyai banyak perbendaharaan bahasa Indonesia.

\section{SIMPULAN}

Penerapan pendekatan kooperatif metode struktural dengan teknik mencari pasangan dapat meningkatkan keterampilan berbicara pada SD Negeri 060890 kecamatan Medan Polonia. Berdasarkan kesimpulan di atas, beberapa hal yang sebaiknya di lakukan oleh guru dalam meningkatkan kualitas pembelajaran untuk memperoleh hasil yang memuaskan, di antaranya:

1. Guru perlu mengadakan evaluasi dalam setiap pembelajaran Bahasa Indonesia guru mengetahui kekurangankekurangan untuk di perbaiki dan keberhasilan-keberhasilan yang di capai untuk di pertahankan.

2. Guru hendaknya memiliki kemampuan yang baik dalam menganalisa permasalahan yang terjadi dalam suatu pembelajaran Bahasa Indonesia.

3. Guru harus pandai menumbuhkan minat, daya tarik dan motivasi siswa terhadap mata pelajaran Bahasa Indonesia khususnya materi berbicara.

4. Guru harus dapat memberi kesempatan siswa untuk berperan 
aktif dalam proses pembelajaran.

Guru hendaknya menggunakan alat peraga/media dalam pembelajaran.

5. Guru harus menciptakan lingkungan yang kondusif guna mendukung keberhasilan pembelajaran.

\section{DAFTAR RUJUKAN}

Akhmad Rofi'udin, Darmiyati Zuhdi, 2001 Pendidikan Bahasa dan Sastra Indonesia di Kelas TinggI. Universiatas Negeri Malang.

Isjoni. 2009. Cooperatif Learning. Bandung: Alfabeta.

Marthinis Yamin. 2007. Kiat Membelajarkan Siswa. Jakarta: Gaung Persada Press.
Oemar Hamalik. 2009. Proses Belajar Mengajar. Jakarta: Bumi Aksara.

Sobry Sutikno. 2009. Belajar Dan Pembelajaran. Bandung: Prospect.

Pupuh Fathurohman. 2009. Strategi Belajar Mengajar. Bandung: Refika Aditama.

Muhammad Arifin. 2009. Meningkatkan Kemampuan Berbicara dengan Pembelajaran Kooperatif Model Struktural pada Siswa Kelas IV SDN Rebalas Grati Pasuruan, diakses pada tanggal 29 Juni 2010 pukul 19.00. 